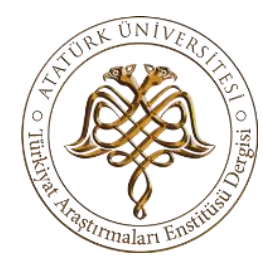

\title{
1894 İSTANBUL DEPREMINDE İZMIT'TE AFET VE KRİZ YÖNETIMI
}

\section{DISASTER AND CRISIS MANAGEMENT IN IZMIT IN THE 1894 ISTANBUL EARTHQUAKE}

\section{YUNUS ÖZGER}

Prof. Dr. Yozgat Bozok Üniversitesi Fen-Edebiyat Fakültesi Tarih Bölümü Prof. Dr. Yozgat Bozok University, Faculty of Science and Letters, Department of History yunusozger@gmail.com

iD https://orcid.org/0000-0002-2830-9515

Türkiyat Araştırmalan Enstitüsü Dergisi - Journal of Turkish Researches Institute TAED-65, Mayıs - May 2019 Erzurum

ISSN-1300-9052

Makale Türü-Article Types : Araştırma Makalesi-Research Article

Geliş Tarihi-Received Date : 28.01 .2019

Kabul Tarihi-Accepted Date : $\quad$ 25.05.2019

Sayfa-Pages : $333-346$

doi : http://dx.doi.org/10.14222/Turkiyat4139

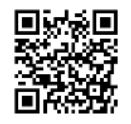

www.turkiyatjournal.com http://dergipark.gov.tr/ataunitaed

This article was checked by

$\checkmark$ iThenticate 



\author{
Atatürk Üniversitesi • Atatürk University \\ TÜRKIYAT ARAŞTIRMALARI ENSTITÜSÜ DERGISI \\ JOURNAL OF TURKISH RESEARCHES INSTITUTE \\ TAED-65, 2019. 333-346
}

\title{
1894 İSTANBUL DEPREMİNDE IZZMIT'TE AFET VE KRIZZ YÖNETIMİ \\ DISASTER AND CRISIS MANAGEMENT IN IZMIT IN THE 1894 \\ ISTANBUL EARTHQUAKE
}

\section{YUNUS ÖZGER}

\begin{abstract}
$\ddot{O} \mathbf{z}$
Türkiye'de deprem riski taşıyan en yüksek yerlerden biri İzmit ve çevresidir. Eskiçağlardan günümüze kadar bölgede çok ciddi depremler meydana gelmiş ve büyük hasarlar oluşmuştur. Bölgenin sosyal ve ekonomik yapısı olumsuz etkilenmiştir. 10 Temmuz 1894'te meydana gelen depremde İzmit şehir merkezinde cami ve okul gibi tarihi yapılarda ciddi hasar oluşmuş ancak herhangi bir can kaybı yaşanmamıştır. Beklenmedik zamanda ortaya çıkan ve rutin işleyişi bozan bu gibi durumlar kriz olarak tanımlanmaktadır. Depremin neden olduğu kaotik sorunu çözmek için kriz yöneticileri gerekli tedbirleri almışlardır.

$\mathrm{Bu}$ araştırmada afet ve kriz yönetimi bağlamında söz konusu depremin İzmit'e sosyoekonomik etkisi incelenecektir. Arşiv belgeleri ışığında İzmit'te meydana gelen hasar durumu ele alınacak ve İzmit yöneticilerinin krizi yönetme stratejileri tespit edilecektir.

Afet ve kriz yönetim stratejilerine göre, krizin en az zararla atlatılması, idarecilerin yönetim kapasitesiyle doğrudan ilgilidir. Bu süreçte krizden çıkabilmek için hızlı ve sağlıklı karar alınması gerekir. Söz konusu depremde krizi yönetmek için ilk olarak başkent İstanbul'da askeri ve mülki bürokrasi harekete geçmiştir. İzmit mutasarrıfi ile İzmit kumandanı krizi çözmek için büyük çaba göstermişlerdir. İlk olarak İzmit'te kriz merkezi oluşturulmuş ve hasar tespit çalışması yaptırılmıştır. Zarar gören tarihi binalar etraflıca belirlenmiştir. Ardından tadilat ve tamirat süreci başlatılmıştır. Diğer yandan depremzedelere belirli oranda parasal yardım edilmiştir.
\end{abstract}

Anahtar Kelimeler: İzmit, deprem, afet ve kriz, 10 Temmuz 1894

\begin{abstract}
One of the areas with the highest risk of earthquake exposure in Turkey is Izmit and its surroundings. The region has been hit by many serious earthquakes and has suffered great damage since ancient times, and this has affected also the social and economic structure of the region. The earthquake that took place on July 10, 1894 caused great damage to historical buildings in the city center of İzmit, including mosques and schools, although no lives were lost. Events like these, which happen unexpectedly and break the daily routine, are described as crises, and crisis managers have taken the necessary steps to bring order to the chaotic situations caused by earthquakes.

This study examines the socio-economic effect of the earthquake on Izmit, in the context of disaster and crisis management. To this end, archive documents will be used to shed light on the damage suffered in İzmit, and the crisis management strategies adopted by local administrators in the city.

From the perspective of disaster and crisis management strategies, getting over a crisis with the minimum amount of damage is directly related to the management capacity of the administrators. In this process, quick and informed decisions need to be made to overcome the crisis and to manage a crisis following the earthquake, for which the military and administrative offices in Istanbul took action. The governor and commander of İzmit put great effort into resolving the crisis. First, they established a crisis center in İzmit and surveyed the damage, and historical buildings that suffered damage were identified in detail. In the following stage, the processes of repair and renovation were started, and financial aid was provided the victims of the earthquake.
\end{abstract}

Key Words: Izmit, earthquake, disaster and crisis, 10 July 1894 


\section{Giriş}

Kriz terimi, Yunanca kökenli olup yargı, seçim ve karar manasını taşıyan "krisis" kelimesinden gelmektedir. ${ }^{1}$ Kriz durumu, umulmadık zamanda ortaya çıkan, rutini bozan, maddi varlığı tehdit eden ve acilen müdahalenin elzem olduğu durumlardır. ${ }^{2}$ Ekonomik ve sosyal nedenlere bağl krizler ortaya çıkabileceği gibi günümüz şartlarında veri kaybı, fabrika kazası ve terörizm nedenli krizler de yaşanmaktadır. ${ }^{3}$ Ayrıca ansızın ortaya çıkan doğal afetler de krizlere sebep olmaktadır.

Kriz dönemlerinde hızlı ve sağlıklı karar alınması, krizden çıkışı kolaylaştırır. $\mathrm{Bu}$ süreç kriz yönetimi olarak tanımlanır. Konu üzerinde araştırma yapanlar, daha çok ekonomik krizlerin tahlil ve çözümü merkezli olarak kriz yönetimini birkaç aşamada ele alırlar. Doğal afet sonrası süreci de doğrudan ilgilendiren kriz yönetiminin ilk aşaması, krizden kaçınmak yani herhangi bir krizin yaşanmamasına gayret etmektir. Ancak deprem gibi afetlerde bunu sağlamak mümkün değildir. İkinci aşama krizi yönetmeye hazırlanma safhasıdır. Bunun için afetin boyutunun saptanması gerekir. Ardından olumsuz durumun yayılımının dondurulması ya da durdurulması için müdahale edilmeli onun akabinde krizin çözümüne geçilmelidir. ${ }^{4}$

Doğrudan afet yönetimini inceleyen araştırmacılar ise afet öncesi durum, afet anı ve afet sonrası durum şeklinde kategorize ederler. Bu evrede arama kurtarma ve ilk yardım ulaştırma işlerinin organizesi önem arz eder. Bunun yanı sıra mağdurların geçici ikame ve iaşe problemlerinin giderilmesi gerekir. Afet sonrasında ise durumun iyileştirilmesi, tahrip olan mekânların yeniden imar ve inşası ve bunun için gerekli olan fiziki planlamanın yapılması süreçleri izler. ${ }^{5}$

Muhtemel krizlerin olabildiğince az hasarla atlatılabilmesi, yapılacak acil durum planlamasıyla doğrudan ilgilidir. Yönetim kademesi, daha kriz yaşanmadan önce kriz anında yapılacak işleri planlamalıdır. $\mathrm{Bu}$ bağlamda uzmanlardan müteşekkil ekipler oluşturulmalıdır. $^{6}$

10 Temmuz 1894'te Marmara'da meydana gelen ve İstanbul depremi olarak bilinen büyük deprem sosyo-ekonomik sonuçları olan bir krize sebep oldu. Sürecin İzmit'te nasıl idare edildiğine geçmeden önce mezkûr deprem hakkında kısaca bilgi vermek gerekir.

\section{a. 10 Temmuz 1894 İstanbul Depremine Bakış}

Türkiye'de depremselliği en yüksek yerlerden biri şüphesiz Marmara Bölgesidir. İzmit Körfezi ve çevresinde tarih boyunca büyük zelzeleler yaşandığı bilinen bir gerçektir.

\footnotetext{
${ }^{1}$ Tuncer Asunakutlu-Serkan Dirlik, "Kriz Yönetimi Stratejileri ve Kriz Sonrası Yeniden Yapılanma", Kriz Yönetimi, Derleyenler Haluk Sumer, Helmut Pernsteiner, İstanbul Bilgi Üniversitesi Yayınları, İstanbul 2009, s.36. ${ }^{2}$ A. Asuman Akdoğan, Ayşe Cingöz, "Kurumsal İtibar ve Kriz Yönetimi: Kurumsal İtibarı Korumada Kriz İletişiminin Rolü”, Kriz Yönetimi, s.6.

${ }^{3}$ Asunakutlu, Dirlik, "Kriz Yönetimi Stratejileri ve Kriz Sonrası Yeniden Yapılanma", s.37.

${ }^{4}$ Norman R. Augustıne, "Önlemeye Çalıştığınız Krizi Yönetmek", Harvard Business Review on Crisis Management, çev. Salim Atay, BZD Yayıncılık, İstanbul 2000, s.17-35.

${ }^{5}$ Abdullah Yılmaz, Türk Kamu Yönetiminin Sorun Alanlarından Biri Olarak Afet Yönetimi, Pegem Yayıncıllk, Ankara 2003, s.44-67.

${ }^{6}$ Richard Lueckr, Kriz Yönetimi, çev. Önder Sarıkaya, Türkiye İş Bankası Kültür Yayınları, 3. Baskı, İstanbul 2009, s.43.
} 
XIX. Yüzyılda meydana gelen en yıkıcı ve büyük deprem ise 10 Temmuz 1894 Salı günü vuku buldu. ${ }^{7}$

İstanbul'un çevreyle iletişimini sağlayan telgraf hatlarının deprem nedeniyle bir süreliğine kullanılmaz hale gelişi ${ }^{8}$ afet ve kriz yönetimi açısından idareyi zora soktu. Ancak Telgraf ve Posta Nezareti derhal harekete geçerek, çadırlara kurarak, birkaç makine birleştirilerek haberleşmeyi tekrar başlattı. ${ }^{9}$ Depremin hemen ardından padişah II. Abdülhamid, Atina Rasathanesi müdürü ile temasa geçilmesini sağladı ve rasathane müdürü Eginitis ve ekibine deprem raporu hazırlattı. ${ }^{10}$ Kaynaklarda depremin merkez üssünün neresi olduğu hususunda ittifak yoktur. Zelzelenin geniş bir alanda meydana geldiğini söyleyen Eginitis, merkezin tek bir nokta olmadığını ifade eder. Jeoloji konusunda kaleme aldığg tercüme çalışmasında Halil Edhem Bey, depremin merkezinin İzmit körfezi olduğunu söyler. Konuyu Doktora çalışmasıyla inceleyen Özkılıç ise elde ettiği kaynaklar ve vesikalara dayanarak depremin merkez üssünü “Marmara Denizi'nin doğusu ancak İzmit Körfezi'nin Batisinda bir nokta olsa gerektir" şeklinde tanımlar. ${ }^{11}$

Noktasal olarak yer tespiti net olarak yapılamayan felaketin bütün Marmara'yı etkilediği ve büyük tahribata yol açtığı konusunda araştırmacılar hemfikirdir. Deprem, Osmanlı arşiv vesikalarında "zelzele-i müthiş"12, "hareket-i arzıye"13 ve "hareket-i arz"14 şeklinde yer almaktadır.

Dönemin İstanbul Sultanisi Müdürü Ebu'l- Muhsin Kemal tarafindan kaleme alınan, Sultani ve İdadilerde ders kitabı olarak okutulan Yeni İlmü 'l-arz adlı eserde mezkûr depremle ilgili detaylı malumat vardır. Buna göre; 10 Temmuz 1894 Salı günü alaturka saat beşe yirmi kala [12:24] meydana gelen deprem üç büyük sarsıntıyla başladı. Birincisi yandan, diğer ikisi aşağıdan yukarı doğru hissedildi. Bu üç sarsıntı yaklaşık 10-12 saniye sürdü ve büyük hasara yol açtı. Artçı sarsıntılar Perşembe gününe kadar devam etti. Perşembe günü alaturka saat sekiz buçukta birer saniye devam eden şiddetli iki sarsıntı daha oldu ve ardından hafifledi. ${ }^{15}$

\footnotetext{
${ }^{7} 1894$ Depremiyle ilgili ayrıntılı bilgi için bkz. Fatma Ürekli, İstanbul'da 1894 Depremi, İletişim Yayınları, İstanbul 1999; Sema Küçükalioğlu Özkılıç, "1894 Depreminin İstanbul Üzerindeki Etkileri (Deprem Sonrası İmar Faaliyetleri), Marmara Üniversitesi Türkiyat Araştırmaları Enstitüsü Yayımlanmamış Doktora Tezi, İstanbul 2011; Feriha Öztin, 10Temmuz 1894 İstanbul Depremi Raporu, Ankara 1994; Sıddık Çalık, 1894 Yllında İstanbul'da Meydana Gelen Büyük Depreme Ait Anonim Bir Günlük, Üsküdar Belediyesi Yayınları, İstanbul 2003.

${ }^{8}$ Ürekli, İstanbul'da 1894 Depremi, s.15.

${ }^{9}$ Siddık Çalık, 1894 Yllinda İstanbul'da Meydana Gelen Büyük Depreme Ait Anonim Bir Günlük, Üsküdar Belediyesi Yayınları, İstanbul 2003, s.57.

${ }^{10}$ Raporun Osmanlicası için bkz. Başbakanlık Osmanlı Arşivi (BOA). Yıldız Esas Evrakı (Y.EE), nr. 11/24, Günümüz Türkçesine aktarımı için bkz. Hamiyet Sezer, "1894 İstanbul Depremi Hakkında Bir Rapor Üzerine İnceleme”, Tarih Araştrmaları Dergisi, cilt 18, sayı 29, Ankara 1996.

${ }_{11}^{1}$ Özkılıç, "1894 Depreminin İstanbul Üzerindeki Etkileri (Deprem Sonrası İmar Faaliyetleri), s.32, 283.

12 “... Karamürsel kazasina mülhak Yalova Nâhiyesine merbût Gactk karyesi ahâli-i kullarından olup geçen şiddetle zuhûr eden zelzele-i müdhiş-i 'azimeden...” BOA (Başbakanlık Osmanlı Arşivi). BEO (Bâblâli Evrâk Odasi). nr. 443 / 33211, v.4, 22 Temmuz 1894.

13 “...geçenlerde vukû bulan harekât-ı arzıyede...” BOA. Maarif Nezareti Mektûbi Kalemi Evrâkı (MF. MKT). nr. $219 / 30$, v.2. 8 Ağustos 1894.

14 “...dünkü gün sấ at beşe yirmi kalarak İzmid'de şiddetlice hareket-i ‘arz vukû 'bularak...” BOA. Ylldız Mütenevvi (Y. MTV). nr. 99/52, 11 Temmuz 1894.

${ }^{15}$ Ebu'l- Muhsin Kemâl, Yeni İlmü'l-Arz, Artin Asadoryan ve Mahdumları Matbaası, İstanbul 1330, s.89.
} 
Depremin artçı şokları 8 Ağustos 1894'e kadar devam etti. Bunların en şiddetlisi 12 Temmuz 1894 akşamı saat 16.10 'da oldu ve iki saniye sürdü. ${ }^{16}$

Depremle ilgili kaleme alınan anonim bir eserde benzer ifadeler bulunmakta ve deprem hareketinin yönünün Güneydoğudan Kuzeybatıya ve aşağıdan yukarıya doğru olduğu tespitine yer verilmektedir. ${ }^{17}$

Muhsin Kemal'in depremin süresiyle ilgili verileri dönemin basın yayın organlarında birbirinden farklı şekilde gösterilmiştir. 10-12 saniye verenler olduğu gibi, 30 saniye hatta 1 dakika olarak gösterenler bile vardır. ${ }^{18}$ İstanbul Rasathanesi müdürü Coumbary ve yardımcısı Emil Lacoine'in de içinde yer aldığı ve 15 Ağustos 1894'de padişaha sunulan Eginitis' in raporunda ise deprem anı şu şekilde tasvir edilmiştir:

“... Salı günü öğleden sonra saat 12:24'te ü̧ defa şiddetli bir sarsintı meydana gelmiştir. Illk sarsintıdan bir-iki saniye önce arabalar geçiyormuş gibi yer altından sesler gelmiştir. Bu ilk hareket 4-5 saniye sürmüş̧ür. Ancak şiddeti daha sonra artmıştır. Ikinci sarsintı çok şiddetli olup 8-9 saniye sürmüş ve bunun neticesinde büyük ylkım yaşanmıştır. Üçüncü sarsıntı ikincisine göre daha hafif olmuş ve yaklaşık beş saniye devam etmiştir. Yer, adeta dalgalı bir deniz gibi olmuştur. Artarda gelişen sarsintı toplamda 1718 saniye sürmüştür..."

Heyetin takdim ettiği, depremin etkilediği alanı gösteren haritada depremin merkez üssü birinci kısımda gösterilmiş ve burası en çok zarar gören yer olarak işaretlenmiştir. Rapordan anlaşıldığına göre hattın büyük ekseni Çatalca'dan Adapazarı'na kadar ve İzmit körfezi boyunca $175 \mathrm{~km}$ uzunluğunca devam etmiştir. Küçük ekseni ise İzmit Körfezi yakınında Katırlı (Esenköy) Köyü ve Maltepe köyleri arasındaki 39 km uzunluğundaki alandır. ${ }^{20} \mathrm{Bu}$ kadar geniş bir bölgeyi etkisi altına alan depremden İstanbul'un dışında en çok zarar gören yerlerin başında şüphesiz araştırma sahamız olan İzmit yöresi gelmektedir.

Deprem, İzmit' in dışında Yanya, Bükreş, Girit, Yunanistan, Konya ve Anadolu'nun büyük bir kesiminde hissedildi. Yıkıcı depremde İstanbul'da 474 kişi hayatını kaybetti, 482 kişi yaralandı. Yapılarda büyük tahribat oluştu, 387 dayanıklı yapı ve 1087 ev, 299 dükkân büyük ölçüde hasar gördü. ${ }^{21}$ Deprem en çok sur içi İstanbul'u etkiledi. Büyük felakette 20.959'u sivil toplam 22.500 bina hasar gördü ve bunun 20.300'ü İstanbul sınırları içindedir. Bunlardan 10.171 adedi birinci derece hasarliydı. ${ }^{22}$ Deprem sonrası basına uygulanan sansür nedeniyle gerçek ölü ve yaralı sayısının net olarak tespit edilemediğini ileri süren araştırmacılar, resmi verilerin üç ya da beş katı daha fazla kaybın olduğunu iddia etmektedirler. Bu durumda İstanbul sınırları dâhilinde depremde hayatını kaybedenlerin

\footnotetext{
${ }^{16}$ Öztin, 10 Temmuz 1894 İstanbul Depremi Raporu, s.11.

${ }^{17}$ Çalık, 1894 Yllında İstanbul'da Meydana Gelen Büyük Depreme Ait Anonim Bir Günlük, s.5.

${ }^{18}$ Özkılıç, “1894 Depreminin İstanbul Üzerindeki Etkileri”, s. 9.

${ }^{19}$ Hamiyet Sezer, "1894 İstanbul Depremi Hakkında Bir Rapor Üzerine İnceleme”, Tarih Araştırmaları Dergisi, cilt 18, say1 29, Ankara 1996, s.173; Ürekli, İstanbul'da 1894 Depremi, s.17.

${ }^{20}$ Öztin, 10 Temmuz 1894 İstanbul Depremi Raporu, s.11.

${ }^{21}$ Sezer, "1894 İstanbul Depremi Hakkında Bir Rapor Üzerine İnceleme”, s.171; Öztin, 10 Temmuz 1894 İstanbul Depremi Raporu, s.9.

22 Özkılıç, “1894 Depreminin İstanbul Üzerindeki Etkileri”, s.283.
} 
toplam sayısının yaklaşık 1500-2400 arasında olabileceği, yaralı sayısının ise 1500-2500 dolayında olabileceği iddia edilmektedir. ${ }^{23}$

\section{b. Afet ve Kriz Yönetimi Açısından Depremde İzmit'in Durumu}

Deprem gibi beklenmeyen büyük doğal afetlerin sonrasında ortaya çıkan kriz durumu, yörenin idarecilerinin yönetim kapasitesinin tespiti açısından büyük önem taşır. Krizi yönetmek üzere evvela başkent İstanbul'da askeri ve mülki bürokrasi iki kanattan harekete geçirildi. Emir-komuta zincirinin işlevselliği nedeniyle askeri iletişim kanalı daha hızlı çalıştı. Komşu şehirlerde durum tespitinin yapılması için derhal talimatlar gönderildi ve askeri kanat marifetiyle depremin bilançosu çıkarılmaya çalışıldı. Yaşanan büyük felaketten çıkış yolları aranırken bir yandan da kutsal mekânlarda bu tür afetlerin yaşanmaması için dualar edildi. ${ }^{24}$

\section{Hasar Tespit ve Tahliye Çalışmaları}

Afet yönetiminde iletişim hattının iki ucunun da aktif çalışması büyük önem arz eder. Nitekim deprem anında İstanbul telgraf hattı kısa süreliğine devre dışı kaldı ise de daha sonra haberleşme yeniden başlatıldı. İzmit mutasarrıflığı depremin olduğu andan itibaren şehirdeki durumu ivedilikle İstanbul'a iletme imkânı elde etti. ${ }^{25}$ İzmit'e bağlı yerleşim birimleri de kaymakamlıklar aracılı̆̆ıyla duruma İzmit mutasarrıflığına bildirdi. ${ }^{26}$ İzmit kumandanı Ferik Saadeddin Paşa, başkentten aldığı talimat sonrası derhal harekete geçerek, şehirdeki durumu yerinde tespit etmiş ve yine aynı kanal vasıtasıyla durumu Serasker Rıza Paşa'ya bildirmiştir. İzmit kumandanı, raporunda depremin meydana geldiği saati bildirmiş, sarsıntının çok şiddetli olduğunu haber vermiştir. Yaşanan panik anından olsa gerek, mevcut durumu olduğundan abartılı şekilde yansıtmış ve sarsıntının yaklaşık beş dakika sürdüğünü iddia etmiştir. Kumandanın yerinde yaptırdığı tespitlere göre deprem nedeniyle İzmit merkezde herhangi bir can kaybı yaşanmamıştır. Ancak Fevziye Camii başta olmak üzere bazı tarihi

\footnotetext{
${ }_{23}^{23}$ Öztin, 10Temmuz 1894 İstanbul Depremi Raporu, Ankara 1994, s.9

24 “... Dersa'âdet ve havâlisinde hâdis harekât-ı arziyenin 'adem-i tekerrürü ve ba 'zl vilâyât-l şâhânede devâm eden kolera hastallğının hemân ve külliyen ref" u izâlesi ve füzûni-i ömr ü şevket-i hazret-i pâdişâhîye de 'avât-ı hayriyesi dâhil-i envâr-l şâmil-i harem-i şerîfde bâb-ı beyt-i mu 'azzam küşâde olduğu halde ve Taif'de hazret-i Abdullah ibn-i Abbas raziyallahu anhumâ efendimizin huzurlarında Buhâri-i şerif kırâ'at olunduğunu müte 'akıb tilâvet ve tekrâr kilındığı gibi huzûr-ı hazret-i sultânü'l-enbiyâ aleyhi efzâlü 't-tehâyada dahi münâcâat-ı lâzimede bulunulması..." BOA. Yıldız Sadâret Husûsî Ma 'rûzât Evrâkı (Y. A. HUS). nr. 311 / 79, v.4, 27 Ağustos 1894; Ayrıca Şeyhülharem Mehmed Adil bin Halid'in gönderdiği yazıda ifade edildiğine göre Cuma günü, namazın ardında Hz. Muhammed'in Medine'deki kabri önünde bu tür felaketlerin tekrar etmemesi için topluca dua edilmiştir. Bkz. “... harem-i şerîf-i hazret-i nebevîde dahi ol-vechle münâcât-ı hayriyenin icrâ ve 'arz ve inbâsı ..." BOA. Y. A. HUS. nr. 311 / 79, v.3, 15 Ağustos 1894.

${ }^{25}$ Örneğin İzmit Mutsarrıflı̆̆nın İstanbul'a gönderdiği 10 Temmuz 1894 tarihli telgraf şu şekildedir: “...bugün sa 'ât beşe yigirmi kala İzmid kasabasindan garbdan şarka doğru biri şiddetli diğeri hafif̧̧e hareket-i arz vuku' bulmuş ve lehü'l-hamd ve'l-minne nüfusça bir gûne vefeyât yoğ ise de Fevziye câmiinin nısf-ı minaresi ve ba'zl dekâkin ve ebniyenin ylkılarak tahkîkât-ı lâzime icrâ kllınmakda idüğ̈̈ ma 'rûzdur..." Saadet Gazetesi, Numro: 3020, 8 Muharrem 1312, s.1; Çalık, 1894 Yllinda İstanbul'da Meydana Gelen Büyük Depreme Ait Anonim Bir Günlük, s.94-95.

26 “....Karamürsel kasabasındaki depremden bir cami ve minaresi yıklmış ise de nüfusça bir güne telefât olmadı̆̆ kaymakamliklarından gelen telgrafnâmelerden anlaşılmış..." Çalık, 1894 Yllında İstanbul'da Meydana Gelen Büyük Depreme Ait Anonim Bir Günlük, s.95.
} 
yapılar büyük hasar görmüştür. Söz konusu caminin minare şerefesinin üst tarafı cami üzerine düşmüş ve cami tamamen kullanılamaz hale gelmiş̧tir. Bunun yanı sıra Sultan Orhan Gazi Camiinin de minaresi yıkılmıştır.

İzmit mutasarrıfi Selim Sırrı Paşa, afet yönetiminin önemli enstrümanlarından biri olan basın-yayın organlarından yeterince istifade etmiștir. İzmit'te yaşanan deprem, aynı gün mutasarrıfın ilettiği haber doğrultusunda Saadet Gazetesi'nde yer almıştır. ${ }^{27}$ Mutasarrıf, sadece İzmit merkezdeki durumu değil aynı zamanda o dönemde İzmit mutasarrıflığına bağlı olan Adapazarı'ndaki ahval hakkında da bilgiler göndermiştir. Selim Sırrı Paşa, sorumlu bir idareci vasfina uygun hareket etmiş ve bizzat trenle Adapazarı'na giderek yerinde gözlem yapmıştır. Depremi bütün şiddetiyle hisseden Adapazarı'nda birçok ev kullanılamaz hale gelmiş hatta enkaz altında kalanlar olmuştur. Geyve kazası da benzer biçimde depremden etkilenmiş ancak burada can kaybı yaşanmamıştır. Karamürsel'de bir cami ile minaresi tamamen yıkılmış ve burada da can kaybı yaşanmamıştır. ${ }^{28}$

$\mathrm{Bu}$ ilk durum değerlendirmesi sonrasında detaylı hasar tespit çalışmasına başlanmıştır. Depremin ilk şoku atlatıldıktan sonra yapılan tespitler durumu daha net olarak ortaya çıarmıştır. Afet yönetiminin ilk aşamalarından biri olan afetin boyutunun ortaya çıkarılması bağlamında hasar tespit raporları tanzim edilmiştir. Bu raporlara göre İzmit merkezde yer alan Kasr-1 hümayunda ve askerin ikametine tahsis edilen askeri dairelerin bazı bölümlerinde ciddi hasarlar meydana gelmiştir. Redif deposu ile askeri daire duvarlarında çatlaklar oluşmuştur. İzmit merkez, felaketi kayıpsız atlatmış ancak İzmit Sancağına bağlı bazı yerleşim alanları bu kadar şanslı olamamıştır. Örneğin Adapazarı'nda birçok ev kullanılamaz hale gelmiş ve raporun yazıldığı esnada sayısı tespit edilememekle beraber hayli nüfus hayatını kaybetmiştir. Yine Adapazarı'nda askeri deponun duvarı tehlikeli biçimde yarılmış, silah ve askeri eşyanın oradan başka bir yere nakli zorunluluğu ortaya çıkmıştır. Sapanca'da süvari mülazımı Ahmed Efendi deprem esnasında kendisini pencereden atmış ve ayağı zedelenmiştir. ${ }^{29}$

Deprem anında İstanbul'da yaşananların doğrudan anlatıldığı anonim bir günlüğe benzer bir kaynak İzmit için bulunamadığından felaket anında yapılan çalışmalar hakkında detaylı bilgi elde edilememektedir. Mezkûr günlükte bahsedilen Kumkapılı Doktor Dobreş Efendi'nin emri altındaki iki Avrupalı doktoru depremzedelere yardım için sevk edişine benzer durumun İzmit'te yaşanıp yaşanmadığı ne yazık ki bilinememektedir. ${ }^{30}$

Afetin boyutunun tespitinin ardından kriz yönetiminin bir sonraki aşaması olan hasarlı bölgelerin tahliyesi aşamasına geçilmiştir. Süreci Serasker Rıza Paşa merkezden idare etmiş ve gönderdiği talimatlarla hasarlı kamu binalarının özellikle askeri yapıların derhal tahliyesini sağlamıştır. Askerler daha güvenli yapılara taşınmıştır. Mülki idare ise belediye

\footnotetext{
${ }^{27}$ Saadet Gazetesi, Numro: 3020, 8 Muharrem 1312, s.1.

28 “.... bi'z-zat Adapazarı' na müteveccihen İzmid'den tren-i mahsûsla hareket edilüp îcâb-ı icrâ ve netice-i keyfiyetin 'arz ve inhâ kllınacağı ma 'rûzdur...” Saadet Gazetesi, Numro: 3020, 8 Muharrem 1312, s.1.

29 “.... İzmid'de şiddetlice hareket-i arz vukû ' bularak beş dakika devâm ettiği ve lehü'l-hamd nüfusça bir gûne zâyi ât olmayup ...” BOA. Y. MTV. nr. 99/52, 10 Temmuz 1894.

30 “... Doktor Dobreş Efendi, depremzedelere ve tedaviye muhtaç olanlara insani yardım maksadıyla alelacele emri altında bulunan Avrupalı iki doktoru göndererek ... ” bkz. Çalık, 1894 Yllında İstanbul'da Meydana Gelen Büyük Depreme Ait Anonim Bir Günlük, s.21.
} 
mimarları marifetiyle zarar gören diğer kamu binalarının tespitini yapmış, tamiratın ne kadar masrafla mümkün olabileceğini hesaplatmıştır.

Dâhiliye Nezâreti, seraskerlik makamından daha yavaş hareket etmiştir. Vakanın üzerinden yaklaşık iki hafta geçtikten sonra İzmit ile beraber Hüdavendigar ve Aydın vilayetlerine resmi yazılar göndererek durum değerlendirmesi yapmıştır. Nezaret, 10 Temmuz 1894'ten beri vilayet ya da livanın hangi mahallinde, ne zaman ve kaç defa deprem oluştuğunun bilgisini istemiştir. Bunun yanı sıra depremde ölen ve yaralananların sayısı ile binalardaki hasar durumunun da bildirilmesini talep etmiştir. ${ }^{31}$

Nezaretin talimatı üzerine gerekli tahkikatı yaptıran İzmit mutasarrıfı Selim Sırrı Paşa, aradan geçen zamana bağlı olarak sağlıklı veriler elde etmiş ve bunları Dâhiliye Nezareti'ne göndermiştir. Raporuna zelzelenin vuku bulduğu tarih ve zelzelenin şiddetiyle başlayan mutasarrıf, Karamürsel ve Yalova'da beş kişinin enkaz altında kaldığını ve on bir kişinin de yaralandığını bildirmiş̧ir. Yine rapora göre, Yalova'da birkaç çiftlik binası tamamen yıkılmıştır. Köylerdeki evler ise kısmen zarar görmüştür. Karamürsel'de 170 evde ve diğer binalarda çatlaklar oluşmuş ve yıkılmıştır. ${ }^{32}$

Gönderilen raporlardan anlaşıldığına göre deprem İzmit’te camiden okula, fabrikadan köşke birçok kamu binasını tahrip etmiştir. Bunlar içerisinde en fazla zarar göreni Fevziye Camii olmuştur. Deprem nedeniyle caminin minaresi, cami üzerine devrilmiş ve tamamen kullanılamaz hale gelmiştir. ${ }^{33}$ İzmit çuka fabrikas $1,{ }^{34}$ İzmit tersane çeşmesi ${ }^{35}$ ve İzmit İdadisi depremden etkilenmiş ve bazı bölümleri zarar görmüştür. ${ }^{36}$ İki ilkokul büyük hasar gördüğünden kullanılamaz hale gelmiştir. ${ }^{37}$ Yalova'da bulunan meşhur kaplıcalar da

\footnotetext{
31 “... Dersa 'âdet'te vukû ' bulan hareket-i arz târihinden beri şimdiye kadar livânin / vilâyetin kangı cihetlerinde ve ne zamanlarda kaç kere hareket-i arz vukû ' bulduğu ve bundan dolayı ebniyece sakatlik ve inhidâm vukû ' bulmus ise ebniyenin ne vechle ne sûret ve derece rahnedâr olduklarını ve eşhâsca telefât var ise ..." BOA. Bâbıali Evrâk Odasl (BEO). nr. 443 / 33153, v.1, 26 Temmuz 1894.

32 “....Haziran' 'n yirmi sekizinci günü sa ât beșe çâr-yek kalarak vukû 'bulan șiddetli hareket-i 'arzdan Karamürsel ve Yalova'ca beş nüfus enkaz altında kalarak telef ve on bir kişinin mecrûh ve Yalova'ca birkaç çiftliğin ebniyesi kâmilen ve kurâ hânelerinin kısmen münhedim olduğu ve Karamürsel'de dahi yüz yetmiş hâne ve ebniye-i sấ ire çatlamış ve ylkılmış idüğü ma 'rûzdur...” BOA. BEO. nr. 443 /33153, v.2, 18 Temmuz 1894.

33 “....hüsn-i hizmet ve gayretleri görülen İzmid belediye re 'is-i sâbık Moralızâde İbrahim Edhem Efendi'nin rütbe$i$ sâniye sinıf-ı sânisi ve belediye çavuşlarından Halid Efendi ile Ohannes Azaryan kalfanın beşinci rütbeden mecidî nişân-ı zîşân ile taltîflerine ....” BOA. Dâhiliye Mektûbi (DH. MKT). nr. 2132 / 56, 12 Kasım 1898; BOA. DH. MKT. nr. 2150 / 70, v.1, 19 Aralık 1898.

34 “...İzmid çuka fabrika-ı hümâyûnunun hareket-i arzdan rahnedâr olan mahallerinin icrâ-yı termîmâtı içün sarfi lâzım gelen altmış iki bin doksan beş guruşun emsâli vechle tertibât-l fevkâ l'-âdeden tesviyesi..." BOA. Irâde Husûsî (I. HUS). nr. 30/19, 9 Ekim 1984.

35 “... İzmid Tersanesi'nde bulunan çeşmenin hareket-i arzın te 'sîriyle sakatlanmıls ve mezkûr tersane derûnunda bir mescid-i șerîfe de lüzûm-ı hakiki bulunmuş olmasına binâen kesşi led'el-icrâ ....” BOA. İấde Bahriye (İ. BH). nr. 2 /8, v.2, 27 Ağustos 1895.

36 “... İzmid mekteb-i i dâdisinin harekât-ı arziyeden rahnedâr olan mahallerinin iki bin sekiz yüz on iki guruşla ta 'mîr olumacağı belediye mühendisliğinden bi't-tanzîm...” BOA. Maarif Nezâreti Mektûbî Kalemi Evrâkı (MF. MKT). nr. $229 / 33$, v.4, 28 Kasim 1895.

37 “... geçenlerde vukû ' bulan hareket-i arzîyede zedelenerek ikâmete gayr-ı sâlih bir hâle gelmiş ve ta'mîrât-ı lâzimesim der-dest icrâ bulunmuş olan 'imâret ve mar'aşlı mekâtib-i ibtidâiyesi ...” BOA. MF. MKT. nr. 219/30, v.2. 8 Ağustos 1894.
} 
depremden nasibini almış ve kaplıcaların sıcak suyu bir süre kesilmiş, yaklaşı on sekiz saat sonra tekrar ortaya çıkmıştır. ${ }^{38}$

Hasar tespit ve tahliye işlemleri ardından diğer bir aşamaya geçilmiş ve tahrip olan mahallerin yeniden tadilat ve inşa süreci başlamıştır.

\section{Tadilat ve İnşa Süreci}

Zarar gören mekânların tadilatı ve yeniden inşası süreci, afet ve kriz yönetiminin önemli safhalarından biridir. Ancak İzmit, bu süreci hızlıca atlatamamıştır. Bunun en önemli sebebi, İstanbul'da tahrip olan bina sayısının fazla oluşu ve masrafların bütçeye büyük yük getirmesidir. Örneğin İzmit Fevziye Camii, deprem sonrası yeniden inşa edilmeye başlanmış ancak bu süreç yaklaşık dört yıl devam etmiştir. ${ }^{39}$ İzmit Çuka Fabrikasının zarar gören bölümlerinin tamiratı için keşif yapılmış ve ilgili birimlerin çalışmaları neticesinde 62.095 kuruşa ihtiyaç duyulduğu anlaşılmıştır. Mevcut bütçe kaleminde para olmadığından masraflar, tertibat-1 fevkalade yani olağanüstü harcamalar kaleminden karşılanmıştır. ${ }^{40}$

Tersane çeşmesi tamirine ancak bir yıl sonra karar verilebilmiştir. Tersane çalışanları, bunu adeta firsata çevirerek ihtiyaçları olan bir mescidin de bu arada inşasını istemişlerdir. $\mathrm{Bu}$ bağlamda çeşmenin tamiratı için 8.683,5 kuruşa ihtiyaç duyulmuş, inşası düşünülen mescit için 17.493,5 kuruş masraf ön görülmüştür. Ancak depremin meydana getirdiği olağanüstü harcamalar nedeniyle ekstra bir masrafin yapılması pek mümkün gözükmemiştir. $\mathrm{Bu}$ nedenle Bahriye Nezareti söz konusu mescidin malzemelerinin farklı şekillerde temin edilerek çok cüzi bir harcamayla inşa edilmesini önermiştir. ${ }^{41}$ Gerçekten de sözü edilen mescit, etraftaki yapılardan arda kalan kereste ve kiremitlerle yapılmış bütçeden para harcanmamıştır. Dışarıdan getirilen taşların tersanede eritilmesiyle elde edilen kireçle sıva yapılmıştır. Çiviler, hurda malzemeden sağlanmıştır. Kapı ve çerçeveler ise güverteler için biçilecek ağaçların kapak tahtalarından İzmit tersanesinin marangozlarına imal ettirilmiştir. Böylece daha önce ayrılması istenilen 17.493,5 kuruşluk bütçeden yaklaşı \% 60 oranında tasarruf sağlanmış, sadece iş̧̧i yevmiyesi ve cam giderlerinden ibaret toplam maliyet 5.320 kuruş olmuştur. ${ }^{42}$

Bazı bölümleri zarar gören İzmit İdadisinin tamiratı için okul müdürü Abdullah Selim Efendi fevkalade çaba göstermiştir. Depremden bir ay sonra müracaatta bulunmuş ve

38 “...Geçen gün vukûbulan hareket-i arz üzerine emlâk-ı seniyye-i cenâb-ı mülûkâneden bulunan Yalova kaplıcalart sicak suyunun cereyânı munkati' olarak bi inâyetu'l-lah-i te 'âla on sekiz sâ' 'at sonra cereyân etmeğe başladığı ma 'rûzdur...” BOA. Ylldız Perâkende Askeri Marûzât (Y. PRK. ASK). nr. 99 / 18, 14 Temmuz 1894.

${ }^{39}$ BOA. DH. MKT. nr. 2132 / 56, 12 Kasım 1898; BOA. DH. MKT. nr. 2150 / 70, v.1, 19 Aralı 1898.

40 “...İzmid çuka fabrika-ı hümâyûnunun hareket-i arzdan rahnedâr olan mahallerinin icrâ-yı termîmâtt içün sarfi lâzım gelen altmış iki bin doksan beş guruşun emsâli vechle tertibât-l fevkâ'l-âdeden tesviyesi..." BOA. İ. HUS. nr. 30/19, 9 Ekim 1984.

41 “... İzmid Tersanesi'nde bulunan çeşmenin hareket-i arzın te'sîriyle sakatlanmış ve mezkûr tersane derûnunda bir mescid-i şerîfe de lüzûm-ı hakiki bulunmuş olmasina binâen keş̧i led'el-icrâ ....” BOA. İ. BH. nr. 2 /8, v.2, 27 Ağustos 1895.

42 “... İzmid Tersanesi'nde bulunan çeşmenin hareket-i arzın te 'sîriyle sakatlanmıs ve mezkûr tersane derûnunda bir mescid-i şerîfe de lüzûm-ı hakiki bulunmuş olmasina binâen keşfi led'el-icrâ ....” BOA. İ. BH. nr. 2 /8, v.2, 27 Ağustos 1895. 
belediye mühendisleri marifetiyle hasar tespiti ve keşif yaptırmıştır. ${ }^{43}$ Tamirat için ihtiyaç duyulan 2.812 kuruşun bir an önce gönderilerek, okulun eğitim öğretim dönemine hazır edilmesini talep etmiştir. ${ }^{44}$ Ancak başvurusu bürokrasiye takılmış ve okulun tamiri gecikmiştir. İlk olarak gönderilen keşif defterinin belediye ve idare meclisi tarafindan onaylanması gerektiği beyan edilmiş ve evraklar iade edilmiştir. ${ }^{45}$ Abdullah Selim Efendi, bu defa kış mevsimi gelmeden tamiratın yapılması yollarını aramıştır. ${ }^{46} 28$ Kasım 1895 'te Maarif Nezareti'ne tekrar bir yazı yazmış ve kış gelmeden bir an evvel ivedilikle tamirin yapılmasını tekrar istemiştir. Ancak Aralık ayının ortalarına gelindiği halde hala yazışmalar sürmüştür. 19 Aralık 1895 'te tamirat evrakları tetkik için Şehremanetine sevk edilmiştir. ${ }^{47}$ Böylece depremin üzerinden nerdeyse bir buçuk yıl geçmesine rağmen arzu edilen tamirat gerçekleşmemiş̧ir.

Abdullah Selim Efendi, bir yandan okulun zarar gören yerlerini onarma çabası içerisinde iken diğer taraftan okulun sağlam bölümlerini depremden zarar gören diğer mekteplerin geçici olarak kullanmalarının yolunu açmıștır. Bu bağlamda tamamen hasarlı durumda olan İmaret İptidai mektebi ile Maraşlı İptidai mektebinin ${ }^{48}$ öğrencilerinin sıkıntısını gidermeye çalışış̧tır. İdadi müdürü Abdullah Selim, söz konusu iki okul öğrencilerinin geçici olarak, kendi okullarının alt katında boş duran sınıflara nakledilebileceğini teklif etmiştir. ${ }^{49}$ Öneri kabul edilmiş ve böylece çocukların eğitim öğretimi idadi mektebinde sürdürülmüştür.

İmar ve inşa faaliyetinin zamana yayıldığı diğer bir kamu binası ise İzmit Kasr-1 Hümayunu olmuştur. Girişimler hemen başlamasına rağmen tamirat izni ancak dört yıl sonra 24 Ağustos 1898 'de alınabilmiştir. ${ }^{50}$ Hazine-i Hassa Nazırı Sakızlı Ohannes Paşa, izin sonrasında bir keşif heyeti tertip ettirmiş̧ir. Keşif ekibi iki seçenek sunmuşlardır. İlkinde kasıın tam teşekküllü tamiri ve tefrişatının yapılması önerilmiştir. Bu durumda 144.138 kuruşa ihtiyaç duyulacağı belirlenmiştir. İkinci seçenekte ise sadece gözle görülen yerlerin tamiri ve paşa dairesi haricindeki yerlerin onarımı ön görülmüş ve bunun için 45.320 kuruşa

\footnotetext{
43 “... İzmid mekteb-i i dâdisinin harekât-ı arziyeden rahnedâr olan mahallerinin iki bin sekiz yüz on iki guruşla ta 'mîr olunacağı belediye mühendisliğinden bi 't-tanzîm...” BOA. MF. MKT. nr. 229/33, v.4, 28 Kasim 1895.

44 “....mektebin küşâdından mukaddem ta 'mîrâtın icrâsına ...” BOA. MF. MKT. nr. 229/33, v.6, 20 Ağustos 1894.

45 "....sene-i hâliye inşâât tertîbinden tesviyesi lâzım gelür ise de mürsel keșf varakasinın belediye ve idâre-i meclislerince tasdîki lâzım geldiğinden li-ecli 't-tasdîk mezkûr keșf varakasının i âdesi...” BOA. MF. MKT. nr. 229 /33, v.7, 17 Eylül 1894

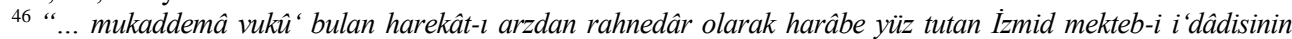
ta 'mîri zımminda bi't-tanzîm ale'l-usûl belediye ve idâre meclislerince... tasdîk kllınan keșf defteri mûcebince mecidî yigirmi guruş hesâblyla iki bin sekiz yüz on iki guruşun sarfiyla mevsim-i şitâ hulûl etmeden..." BOA. MF. MKT. nr. 229 /33, v.2, 12 Eylül 1895.

47 “...iş bu tahrirâtryla sarfina lüzûm gösterilen iki bin sekiz yüz on iki guruşu hâvî idâre-i livâ ve belediyeden musaddak melfûf kessf defterinin li-ecli 't-tetkîk șehremânet-i celîlesine irsâl buyrulması... ” BOA. MF. MKT. nr. 229 /33, v.5, 19 Aralik 1895.

48 "... geçenlerde vukû bulan hareket-i arzîyede zedelenerek ikâmete gayr-ı sâlih bir hâle gelmişs ve ta mîrât-ı lâzimesim der-dest icrâ bulunmuş olan 'imâret ve mar 'aşlı mekâtib-i ibtidâiyesi ...” BOA. MF. MKT. nr. 219/30, v.2. 8 Ağustos 1894.

49 "....mekâtib-i ibtidâiyesi talebesinin muvakkaten ve hâl-i tehlikeden vikâyeten İzmid mekteb-i i dâdisinin hâli bulunan alt kat odalarina naklettirilerek ...” BOA. MF. MKT. nr. 219/30, v.1. 4 Ağustos 1894.

50 “...İzmid'de bulunup hareket-i arzdan ba'zı mahalleri zedelenmiş olan kasr-ı hümâyûnun mükemmelen ta 'mîri ve tefrî̧̧i irâde ve fermân buyrulduğu ...” BOA. Hazine-i Hassa İrâdeler (HH. İ). nr. 118 / 33, 8 Eylül 1898.
} 
ihtiyaç olacağı hesaplanmıştır. Tefrişat giderleri hariç tutulmuştur. Padişahın kullanacağı dairenin tefrişi için ayrıca 15-20 bin kuruş gerekmiştir. Durum değerlendirmesi yapan Ohannes Paşa, mevcut bütçe hesabına uygun olarak ikinci seçeneğin kabulünü talep etmiştir. ${ }^{51}$ Önerisi padişahça aynen kabul görmüş ve böylece İzmit kasrının sadece görünen kısımlarının onarımı gerçekleştirilmiştir.

\section{Halka Yapılan Yardımlar}

Depremin boyutunun ve meydana gelen hasarın tespiti ve hasarlı binaların tahliyesi sonrasında kriz yönetiminin sonraki aşamasına geçilmiştir. Afet yönetiminin bu safhasında felaketten etkilenen ahalinin ihtiyaçlarının tespiti ve giderilmesi çalışmaları yapılmıştır. $\mathrm{Bu}$ bağlamda İstanbul'daki muhtaçlara yardım komisyonu (İâne-i Musâbîn Komisyonu) ile koordineli hareket edilmiştir.

Osmanlı Devleti'nin bu tür felaket zamanlarında ilk yardım, iaşe ve barınma yerleri temin edecek kurumlara sahip olmaması ${ }^{52}$ organizasyonu zora sokmuştur. Gerçekte depremden çok kısa bir süre önce böylesi birimlerin teşekkülü için bir çalş̧maya başlanmıştı. Hükümet, deprem başta olmak üzere yangın, sel, kitlık gibi afetlerde zarar görenlere ve ihtiyaç sahiplerine yardım edebilmek için her vilayet merkezinde iane sandığı kurulmasını zorunlu tutmuştu. Yapısal olarak ziraat sandıklarına benzer biçimde örgütlenecek sandığın sermayesinin 1/3'ü sürekli nakit olarak tutulacak, kalan kısım gerektiğinde talep edenlere borç verilebilecekti. Felaket zamanlarında ise ihtiyaç sahipleri vilayet idare meclislerinin bilgileri doğrultusunda gerekli yardımları alabilecekti. Bunun organizesini Ziraat Bankası memurları yapacaktı. Ancak en büyük sorun parasal kaynağın nereden karşılanacağı meselesiydi. Hükümet bunun için çok ilginç bir öneri getirmişti. 1894 'te mümtaz ve muhtar eyaletler dışında ülkenin toplam 16 milyon nüfusa sahip olduğu ve bir defaya mahsus olmak üzere kişi başına 40 para alınması halinde 160 bin Osmanlı lirası sermaye oluşturulması düşünülmüştü. ${ }^{53}$

Tasarı henüz fiiliyata geçirilemeden 1894 büyük Marmara depremi vuku buldu. Afet ya da kriz yönetiminden sorumlu kurumların arama kurtarma ya da ilk yardım ekipleri ne yazık ki mevcut değildi. Devletin deprem sonrası muhtaç halka yönelik geliştirdiği en büyük sosyal politika, ekonomik durumu iyi olanların yardımına başvurmaktı. Bunun organizesi için Iâne-i Musâbîn Komisyonu teşekkül ettirildi. Komisyon, toplanılan paralarla depremzedelere çadır, yiyecek ve giyecek ihtiyaçlarını karşılayacaktı. Komisyonun başkanlı̆ğını bizzat Sultan II. Abdülhamid yaptı. İkinci başkan ve asıl organizatör ise İstanbul şehremini idi. Komisyona gayrimüslim ileri gelenlerinden birer kişi dâhil edildi. İşlerin düzenli icrası için nizamname hazırlandı. Depremzedelere yardım edenlere madalyalar takdim edildi, yardım faaliyetini genişletmek amacıyla İstanbul'da çeşitli konserler tertip edildi. Ülke içinde başlatılan kampanyaların bir benzeri yurt dışında da yapıldı. Bu bağlamda

\footnotetext{
51 “...ta'mîrât ile tefrî̧̧ât-ı ma'rûzanın şılkk-ı sânî vechle icrâsı husûl-ı maksada kâfi ve hâl-i hazır-ı hazineye muvâfik görünmekte...” BOA. HH. İ. nr. 118 / 33, 8 Eylül 1898.

${ }^{52}$ Yasemin Avc1, “Osmanlı Devleti'nde Afet Yönetimi ve 1899 Denizli Depremi”, Uluslararası Denizli ve Çevresi Tarih ev Kültür Sempozyumu Bildiriler, editörler Ayfer Özçelik v.d, Cilt 1, Denizli 2007, s.367.

53 “... memâlik-i mahrûsa-ı hazret-i pâdişâhîde ara sira zuhûra gelen hareket-i arz ve kaht u galâ ve harîk ve seyelân ve kolera ve sâire gibi mesâ ibden müteessir olan fukarâ-yı ahâli hakkinda ....” BOA. DH. MKT. nr. 224 / 30, 14 Nisan 1894.
} 
Avrupa ülkelerinde ve Amerika'da elçilik mensupları yardım ve bağış organizasyonu düzenledi. Washington elçisinin girişimleriyle Amerikan halkının yardımı sağlandı. Avrupa şehirlerinde depremzedeler için yardım komiteleri oluş̧uruldu. ${ }^{54}$

Yardım kampanyasına Sultan II. Abdülhamid'in iki defada yüklü miktar bağış yaparak iştirak etmesi, kampanyaya katılımı çoğalttı. ${ }^{55}$ Depremden yaklaşık kırk gün sonra ülkenin muhtelif yerlerinden 2.874.914 kuruş yardım topladı. Kampanya katılımcıları arasında Mamuretülaziz valisi Enis Paşa, Adliye Nezareti personeli, belediye dairesi muhasebecisi Murad Efendi, Mösyö Şınayder, Vidin İslam ahalisi, muteber tüccardan Nemizade Tahsin Efendi, Halep vilayeti iane komisyonu, Şumnulu Mehmed Efendi, Şumnu Osman pazarı rüssdiyesi muallimi evveli Mehmed Emin Tevfik Efendi, Düyun-1 umumiye meclisi idare eski reisi vard. ${ }^{56}$ Bunun yanı sıra ikinci ordu müşir vekili Mahmud Hamdi Paşa, Ferik Şakir Paşa, Bahriye feriklerinden Süleyman Paşa, Ferik Necip Paşa gibi yüksek rütbeli askerler başta olmak üzere eski, Dâhiliye Nazırı Said Efendi gibi üst düzey yöneticiler de iştirak etti. ${ }^{57}$

Komisyon sadece İstanbul'da ikamet eden depremzedelere yardım etmiyor aynı zamanda depremin tahrip ettiği diğer şehirlerin de yardımına koşuyordu. Bu bağlamda ilk olarak vilayetlere talimatlar gönderildi ve yardıma muhtaç insanların tespit edilmesi istendi. Özellikle İstanbul'da ve kısmen İzmit yöresinde depremden zarar gördüklerini iddia ederek yardım talebinde bulunanların sayısı oldukça fazlaydı. Hükümet, talepte bulunan herkesin mağduriyet derecesinin net olarak tespit edilmesini istiyordu. Bu nedenle İzmit mutasarrıflığına gönderdiği resmi yazıda, depremin hissedildiği mahallerdeki ihtiyaç sahiplerinin mağduriyet derecelerinin ve ihtiyaçlarının etraflıca araştırılmasını rica etti. ${ }^{58}$

İzmit mutasarrıflığı, gerekli tahkikatı yaptıktan sonra muhtaçların ihtiyaç derecelerini ihtiva eden üç defteri komisyona gönderdi. ${ }^{59}$ İlgili yazışmalardan anlaşıldığına göre İzmit civarında en çok mağduriyet yaşayanlar Yalova ve Karamürsel ahalisiydi. Özellikle Yalova Nahiyesine bağlı Gacık köyü sakinlerinin iane ve ibate sorunları had safhadaydı. Köylüler bir araya gelerek imzalı dilekçeyle başvuru yaptılar. Köylerinde mevcut bulunan 80 haneden 65 tanesinin tamamen harap olduğu, 15 'inin yıkılmamakla beraber büyük zarar gördüğü ve tamire muhtaç durumda olduğunu bildirdiler. Evleri yıkılan köylülerin, kendi ifadeleriyle $a c ̧$ ve bî-ilaç kırlarda ve bahçelerde yaşamak zorunda kaldıkları; paraları olmadığından evlerini tamir edemediklerini dile getirdiler. ${ }^{60}$

\footnotetext{
${ }^{54}$ Ürekli, İstanbul'da 1894 Depremi, s.75, 82, 89.

${ }^{55}$ Padişahın ve diğer rical-i devletin bağış tutarları ve toplam bağış dökümü için bkz. Çalık, 1894 Yllında İstanbul'da Meydana Gelen Büyük Depreme Ait Anonim Bir Günlük, s.154.

${ }^{56}$ BOA. Ylldız Mütenevvi (Y. MTV). nr. 103 /3, v.2, 20 Ağustos 1894.

${ }^{57}$ BOA. Y. MTV. nr. 103 / 13, v.2, 21 Ağustos 1894.

58 “... bu makûle haklarında buraca tahkîkât icrâsı gayr-ı kâbil olmağla hareket-i arzın sademât-ı şedîdesine uğrayan mahaller musâbînin derecât-ı musâbet ve ihtiyâçlarının etrafiyla bi't-tahkîk defterlerinin peyderpey irsâli...” BOA. BEO. nr. 443 / 33211, v.1, 25 Temmuz 1894.

59 “...vukû̉'bulan hasârâtın mekâdirini ve musâb olan eşhâsın derece-i ihtyiâcâttnı nâtık ve zîrleri mahalleri hey'etince musaddak ü̧̈ ktt'a defterin gönderildiği...” BOA. BEO. nr. 543 / 40693, 24 Aralık 1894.

60 “...kulları Karamürsel kazasina tâbi' Yalova Nahiyesinin Gack Karyesi ahâlisinden olup on beş gün mukaddem şiddetle vukû' bulan hareket-i 'arzdan musâb olarak me'vâsız ve bununla beraber aç ve bî-ilâç kalarak kirlarda bağçelerde zarûretle imrâr-l evkât ve hayât eylemekte bulunduğumuzdan..." BOA. BEO. nr. 443 / 33211, v.2, 23 Temmuz 1894.
} 
Toplu başvurular yanı sıra Geyve kazası Şahinbey köyü sakinlerinden Zehra Hanım ve Karamürsel'e bağlı Katılı köyü ahalisinden depremzede Çakır Andon'un yaptığı gibi bireysel müracaat da yapılabiliyordu. ${ }^{61}$ Evi tamamen yıkılmış olan Zehra Hanım, devletin kendisine yardım etmesini istemişti. Ancak İane Komisyonu, bireysel başvurulara sıcak bakmıyordu. İzmit, Mudanya ve Gemlik gibi yerleșim birimlerinde ikamet eden depremzedelerin durumlarının idareciler vasıtasıyla bildirilmesini istedi. Muhtaç durumda olanların neye ihtiyaç duyduklarını ve zaruret derecelerinin ne olduğunun yöneticiler tarafindan ayrintilı yazılması istendi. ${ }^{62}$

Komisyon başvuru yapan hemen herkese benzer cevap veriyordu. Depremde kullanılmaz hale gelen İzmit Fevziye Camiinin imamı Hamza Celaleddin Efendi, yıkılan evi için yardım talep ettiğinde aynı cevabı almıştı. ${ }^{63}$ İane Komisyonu, İzmit'te ikamet eden söz konusu şahsın mağduriyet derecesinin ancak mahalli idareciler tarafindan tetkik edilerek bilinebileceğinden yardım talebine olumsuz cevap verdi. ${ }^{64}$ Benzer biçimde İzmit'in Dere Mahallesi sakinlerinden Mustafa Ağa'nın zevcesi Şaziye ve Karamürsel kazasına bağlı Oluklu adlı Bosna muhacir köyü halkından Muharrem ve kardeşi Ahmed'in dilekçeleri aynı gerekçeyle iade edildi. ${ }^{65}$ Yine İlyas Köyünde ve Karamürsel'in Kayacık Mahallesinde bulunan evleri büyük zarar gören Fatma Hanım, komisyona başvurarak evinin harabe olduğunu ve yardım edilmesini istemiş fakat olumlu cevap alamamıştır. ${ }^{66}$

İzmit' in Karabaş Mahallesi sakinlerinden Rabia Hatun, yıkılan evinin tamiratı için muhtardan aldığ ilmühaberle iane komisyonuna başvurmuştur. ${ }^{67}$ Komisyon, bunun da zaruret derecesinin ancak kendi bölgesindeki yöneticiler tarafindan bilinebileceği gerekçesiyle tahkikat yapılması için iade etmiştir.

Bütün bu örnekler, deprem sonrası oluşan kriz durumunun bu aşamasının iyi idare edilmediğini göstermektedir. Yardım organizasyonunun İstanbul'dan koordine edilmesi, İstanbul'da depremzede sayısının çok fazla oluşu, İzmit'in ihtiyaçlarının zamanında karşılanmasını mümkün kılmamıştır. Kriz yönetimi, taşrayı iyi örgütleyemediğinden mağduriyetler kısa sürede giderilememiştir.

\footnotetext{
61 “...Karamürsel kazasina merbût Katırlı karyesi ahâlisinden olup hareket-zede ...Çakır Andon imzâsiyla...” BOA. DH. MKT. nr. $375 / 77,16$ Mayıs 1895.

62 “....gerek bunların gerek ba 'demâ bu yolda vukû ' bulacak mürâcaatlar üzerine musâbînin derecât-l musâbiyet ve ihtiyâçlarının etrâfiyla bi 't-tahakkuk defterlerini peyder-pey bi 't-tanzîm komisyon-ı 'âliye havâle buyrularak..." BOA. BEO. nr. 443 /33211, v.3, 25 Temmuz 1894.

63 “... sâkin olduğu hâne hareket-i arzdan münhedim olarak hâl-ı sefâlet ve perişânide kaldı̆̆ııı ...” BOA. BEO. nr. 495 /37105, v.1, 15 Ekim 1894.

64 “... mûmâileyhin derece-i fakr u zarûreti mahallince bilinebileceği der-kâr bulunmuş olduğundan ...” BOA. BEO. nr. 495 / 37105, v.2, 30 Eylül 1894.

65 “... verilen iki kit'a arzuhâlde istidâ olunmuş ve bunların derece-i fakr u zarlarının mahallince bilineceği..." BOA. BEO. nr. 508 / 3802, v.2, 30 Ekim 1894.

66 “... merkûmânın derece-i ihtiyaç ve hasarın livâ-ı mezkûrca bilineceği tabi “ bulunmuş...” BOA. BEO. nr. 521 / 39049, v.2, 14 Kasım 1894.

67 “...İzmid'in Karabaş Mahallesi sakinlerinden Rabia Hatun mahalle-i mezkûrda mutasarrlf olduğu hânesi hareket-i arzdan külliyen harâb olup ta 'mîrine gayr-ı muktedire bulunduğu ... " BOA. BEO. nr. 540 / 40445, v.2, 16 Aralık 1894.
} 


\section{Sonuç}

İzmit'in içinde bulunduğu Marmara Bölgesi tarih boyunca pek çok yıkıcı deprem yaşamıştır. Afet ve kriz yönetimi bağlamında İzmit'e etkisinin incelemeye çalıștı̆̆ımı 1894 İstanbul depremi de bunlardan biridir. Deprem İstanbul'da olduğu gibi İzmit'te bir tahribata yol açmamıştır. Büyük sarsıntının hemen ardından özellikle askeri bürokrasi kanalıyla İzmitİstanbul arası iletişim kurulmaya çalışılmıştır. Her ne kadar günümüzdeki gibi bir kriz masası resmen oluşturulmasa da askeri ve mülki erkân süreci kontrol altına almaya çalışmışlardır. İstanbul'da bulunan Seraskerlik makamı, İzmit kumandanına emirler göndermiş ve yerinde gözlemler yapılarak sağlıklı bilgi akışı sağlanmıştır. Ancak bu depremde telgraf hatlarının zarar görmesi nedeniyle iletişimde kısa süreli sorunlar yaşanmışıtır. İzmit’teki krizi mutasarrıf Selim Sırrı Paşa ve askeri kumandan Ferik Saadeddin Paşa koordine etmişlerdir. Depremde İzmit merkezde herhangi bir can kaybı olmamıştır. Tarihi Fevziye Camii, kasr-1 hümayun, çuka fabrikası, tersane çeşmesi, askeri bazı yapılar, İzmit idadisi ve iki iptidai mektebi gibi bazı kamu kurumlarında çeşitli derecelerde hasar oluşmuştur. Deprem İzmit'te en çok Yalova yöresini tahrip etmiş̧ir. Gacık Köyü'nde seksen evin altmış beşi kullanılamaz hale gelmiş, diğerleri ciddi hasar görmüştür. Katırlı köyü aynı şekilde büyük tahribat görmüştür. Adapazarı ve Geyve'de çeşitli binalarda hasarlar meydana gelmiştir. Afet yöneticileri, şehrin yeniden imarına katkı sağlayanlara Fevziye Camii örneğinde olduğu gibi ödüllendirme yöntemini kullanmışlardır. Böylece inşa sürecine desteğin artmasını sağlamışlardır.

İzmit mutasarrıfı ve İzmit kumandanı krizin yönetiminde aktif rol oynamışlardır. Özellikle kumandan Selim Sırn Paşa'nın bizzat trenle Adapazarı'na giderek yerinde tespit yapması kayda değerdir. Kriz yönetiminin ilk aşamaları oldukça sağlıklı idare edilmiştir. Ancak son aşaması olan tadilat ve tamirat süreçleriyle muhtaç halka yardımların organizesi konusunda aynı şeyi söylemek olası değildir. İzmit merkez başta olmak üzere Yalova, Karamürsel ve Adapazarı'nda yardıma muhtaç ahalinin talepleri bürokratik engeller nedeniyle istenilen düzeyde karşılanamamıştır. İane komisyonunun genel merkezinin İstanbul olması, İstanbul'un depremde büyük zayiat vermesi, İzmit sakinlerinin taleplerinin ötelenmesinin nedenlerindendir. İzmit merkezli bir komisyon oluşturularak ianelerin yerelde toplanıp dağııılamaması halkın mağduriyetini artırmıştır. Ekonominin bu felaketin neticelerini karşılayacak durumda olmaması, İzmit'te tamiri istenilen binaların tadilat süreçlerini uzatmıştır. 


\section{Kaynaklar}

Arşiv Kaynakları

Başbakanlık Osmanlı Arşivi (BOA)

Bâbıâli Evrâk Odasi (BEO). nr. 443 / 33211, 443 / 33153, 495 /37105, 508 / 3802, 521 / $39049,540 / 40445,543 / 40693$.

Dâhiliye Mektûbi ( DH. MKT). nr. 224 / 30, 375 /77.2132 / 56, 2150 / 70,

Hazine-i Hassa İrâdeler (HH. İ). nr. 118 / 33.

İrâde Bahriye (İ. BH). nr. $2 / 8$.

İrâde Hususi (İ. HUS). nr. $30 / 19$.

Maarif Nezareti Mektûbi Kalemi Evrâk1 (MF. MKT). nr. 219/30, 229/33.

Yildız Esas Evrak (Y. EE). nr. $11 / 24$.

Y1ldız Mütenevvi Maruzât (Y. MTV). nr. 99 /52, 103 /3, 103 / 13.

Y1ldız Perakende Askeri Maruzat (Y. PRK. ASK). nr. $99 / 18$.

Yıldız Sadaret Hususi Maruzat Evrakı (Y. A. HUS). nr. $311 / 79$.

\section{Gazeteler, Kitaplar ve Makaleler}

Akdoğan Asuman, Cingöz Ayşe, "Kurumsal İtibar ve Kriz Yönetimi: Kurumsal İtibarı Korumada Kriz İletişiminin Rolü", Kriz Yönetimi, ss.3-33.

Asunakutlu Tuncer - Dirlik Serkan, "Kriz Yönetimi Stratejileri ve Kriz Sonrası Yeniden Yapılanma”, Kriz Yönetimi, Derleyenler Haluk Sumer, Helmut Pernsteiner, İstanbul Bilgi Üniversitesi Yayınları, İstanbul 2009, ss.33-61.

Augustıne Norman R, "Önlemeye Çalıştı̆̆ınız Krizi Yönetmek", Harvard Business Review on Crisis Management, çev. Salim Atay, BZD Yayınc1lık, İstanbul 2000, ss.11-41.

Avcı Yasemin, "Osmanlı Devleti'nde Afet Yönetimi ve 1899 Denizli Depremi", Uluslararası Denizli ve Çevresi Tarih ev Kültür Sempozyumu Bildiriler, editörler Ayfer Özçelik v.d, Cilt 1, Denizli 2007, ss. 361-367.

Ebu'l- Muhsin Kemâl, Yeni İlmü'l-Arz, Artin Asadoryan ve Mahdumları Matbaası, İstanbul 1330.

Çalık Sıddık, 1894 Yllında İstanbul'da Meydana Gelen Büyük Depreme Ait Anonim Bir Günlük, Üsküdar Belediyesi Yayınları, İstanbul 2003.

Lueckr Richard, Kriz Yönetimi, çev. Önder Sarıkaya, Türkiye İş Bankası Kültür Yayınları, 3. Bask1, İstanbul 2009.

Özkılıç Sema Küçükalioğlu, "1894 Depreminin İstanbul Üzerindeki Etkileri (Deprem

Sonrası İmar Faaliyetleri), Marmara Üniversitesi Türkiyat Araştırmaları Enstitüsü Yayımlanmamış Doktora Tezi, İstanbul 2011.

Öztin Feriha, 10Temmuz 1894 İstanbul Depremi Raporu, Ankara 1994.

Sezer Hamiyet, "1894 İstanbul Depremi Hakkında Bir Rapor Üzerine İnceleme”, Tarih Araştırmaları Dergisi, cilt 18, sayı 29, Ankara 1996, ss.169-197.

Ürekli Fatma, İstanbul'da 1894 Depremi, İletişim Yayınları, İstanbul 1999.

Saadet Gazetesi, Numro: 3020, 8 Muharrem 1312.

Yılmaz Abdullah, Türk Kaти Yönetiminin Sorun Alanlarından Biri Olarak Afet Yönetimi, Pegem Yayıncilık, Ankara 2003 